\title{
Assessment Tax Management Model of Local Governments in Malaysia
}

\author{
Soeb Pawi, David Martin, Wan Zahari Wan Yusoff, Fazira Shafie \\ Universiti Tun Hussein Onn Malaysia, Johor, Malaysia
}

\begin{abstract}
Tax management by local governments has become more challenging due to robust developments. Assessment tax revenue is the main income for local governments which are used to pay for services and maintenance in the local government administrative areas. However, the amount of revenue collected is decreasing due to the serious problem of assessment tax arrears that affect the administrative system and as a corollary, the delivery of services by local governments. This paper represents a preliminary write-up of a Ph.D. research to identify the legal and policy framework involved in the administration of local governments and to particularly review the performance of the Malaysian local government assessment tax collection. This paper will also examine present practices and regulatory barriers in the management of assessment tax to enable the formulation of a model that can best explain the policies, rules and guidelines to solve the collection problem of assessment tax. Hence, the aim of this paper is to establish a assessment tax management model based on best practices. The study involves all local governments in Malaysia. Assessment tax collection statistics for the research include the total revenue and assessment tax arrears for each local government in Malaysia within five years from 2004 until 2008. Respondents for this research involve officials at the Department of Local Government within the administrative areas of local governments in Peninsular Malaysia, Sabah and Sarawak.
\end{abstract}

Keywords: local governments, assessment tax, revenue collection, tax arrears, tax management

\section{Introduction}

Tax income derived is mainly spent for development purposes. Regardless of the development, national and local tax sources are found to be very important to cover such development expenditures in dire need of funding. Financial resources obtained through income tax are the most important resources for many countries whether developed or developing countries. As local government derives its revenue mainly from assessment

Soeb Pawi, Msc., Department of Construction Management and Real Estate, Universiti Tun Hussein Onn Malaysia.

David Martin, Associate Professor, Ph.D., Department of Construction Management and Real Estate, Universiti Tun Hussein Onn Malaysia.

Wan Zahari Wan Yusoff, Associate Professor, Ph.D., Department of Construction Management and Real Estate, Universiti Tun Hussein Onn Malaysia.

Fazira Shafie, Bachelor of Real Estate Management, Department of Construction Management and Real Estate, Universiti Tun Hussein Onn Malaysia.

Correspondence concerning this article should be addressed to Soeb Pawi and Fazira Shafie, Department of Construction Management and Real Estate, Universiti Tun Hussein Onn Malaysia, UTHM. E-mail: soeb@johor.gov.my; faziraaaa@yahoo.com. 
taxes, its financial accounts are always of interest to the public. Financial resources are derived largely from assessment taxes accounting for about $70 \%-80 \%$ of the total revenue obtained not including licenses, rentals, parking compounds, development charges, and the provisions of the State and Federal Government grants and other sources (Johor State, 2009). The assessment tax is a compulsory contribution to be paid by the taxpayer, where the taxpayer in return will receive benefits from the local governments in the form of tangible and intangible services, community facilities, infrastructures and development projects for their enjoyment. Government and economists elucidate that economic development can grow rapidly with the establishment of the tax system as a channel and method for raising national income (Sidek Hassan, 2008).

Thus, local governments should ensure that the management of tax collection can be implemented effectively in the development process and services provided for appropriately. Assessment tax management is described by the procedures specified in the Local Government Act 1976 (Act 171) adopted by all local governments in Peninsular Malaysia whereas Sabah and Sarawak are governed by procedures stipulated in their respective statutes.

Assessment tax management in local governments is becoming more complex due to the vigorous development within the administration of the local governments themselves. The administration and management of local governments which carry the responsibility to develop and provide services in their administrative areas have become increasingly challenging and difficult.

Complete procedures which have been established in the provisions of the act will guide local governments in managing the assessment tax but they do not explain the subtleties of the work process, hence, local governments need to formulate effective strategic planning. According to the Economic Report of the Ministry of Finance, revenue of tax collection performance in local governments throughout the country showed a worrying decline in the rate of decrease of $11.7 \%$ recorded in 2007 and $0.3 \%$ in 2008 . The implications of the tax reduction has resulted in a deficit spending of RM 75 million and RM 1,179 million in 2007 and 2008 due to the higher prevailing costs. Collection of assessment tax revenue statistics generally shows the majority of Malaysian local government collect assessment tax of less than $60 \%$ of the total tax collectible. In the state of Johor, for example, the amount of assessment tax arrears recorded for all local governments amounted to about RM 168 million in 2009 and this is certainly an issue of concern.

The prevalent issue of lower tax revenue in local governments throughout the country continues to pose a very serious predicament. Although there are legislative policies such as the Local Government Act 1976, the MS ISO 9000 and Total Quality Management (TQM), Customer Charter, Star Rating, and others, the difficulties in revenue collection and arrears are still ongoing and pose a serious strain on local governments. This is because there are no guidelines and specific policies or effective measures emplaced in addressing this problem. Therefore, local governments need to take action either to reduce, cancel or postpone development projects even if they are required by the public. This action is not fair because the quality of services and facilities available do not commensurate with the amount of assessment tax payable. Hence, this issue can lead to the existence of assessment tax arrears problems.

The increasing incidence of assessment tax arrears crisis occurred due to the weakness of the local governments themselves in managing their assessment tax. Local governments are often correlated with weak financial management and this is a factor that contributes to the failed performance of local governments in 
achieving good tax revenue collection. The increasing assessment tax arrears become a constraint for local government not only in development expenditures and provision of services but also disrupt the daily business of the smooth administration of local governments. Fixed expenses such as administrative costs, payroll and workers also face this constraint. Many problems that occur in an organisation can directly be attributed to the organisation itself, whether they are caused by internal or external factors. This situation occurs within the local government itself, where there are arrears of assessment taxes due to problems of internal and external weaknesses of the local government organisation.

In the beginning of 2009, the government was urged to give serious attention to the departments involved in the collection and enforcement issues. This situation showed that the critical level of tax revenue collection performance needed to be prioritised and organised immediately with an effective strategy to overcome the problem of tax arrears.

Thus, the objectives of this research are to identify the legal framework and policies involved in the administration of local governments, review the performance of Malaysian local government assessment tax collection and also to review the extent to which the practices and regulatory barriers in the management of the assessment tax can be reformed. The aim of this research is to establish a assessment tax management model based on best practices in Malaysia.

This research focuses and covers the physical aspects that include local governments throughout the country. The scope of assessment tax collection statistics includes the total revenue and assessment tax arrears for each local government in Malaysia within five years from 2004 until 2008. In terms of legal aspects, the research covers the Local Government Act 1976 (Act 171), (Section 127 to Section 16) and other Acts and policies relating to the tax aspects. Respondent in this research involve officials at the Department of Local Government within the administrative areas of local governments in Peninsular Malaysia, Sabah and Sarawak.

Furthermore, the research conducted will benefit policy makers at the Ministry of Housing and Local Government, Department or Division of Local Government at the state level, legal officers, assessment officers and accountants at the local government level as well as tax payers. Through this research, all information pertaining to the management of assessment tax in local governments will be identified to help local governments play their role effectively so that the objectives of achieving administrative efficiency can be attained successfully and effectively.

\section{Related Work}

Local governments are non-profit agencies whose functions are to provide services to the people. As an agent of development, the local government has been empowered by law (Town and Country Planning Act 1976, Act 172) to control and regulate town planning and to approve application for planning permission, development and renovation of premises. Local government finance is a serious issue that impinges on the operation of a local government. Most local governments suffer from a shortage of revenue and their ability to increase expenditure is therefore limited. As local government derives its revenue mainly from assessment taxes, its accounts are always of interest to the public (Sri Hana Dranita, 2006).

Assessment tax can be referred to as the proportion in the general term rates, or rates collected by local governments or local governments to cover expenses for services and development (Bardai, 1987). Rating is a 
process of determining a value for the levy of withholding tax on people who enjoy the facilities provided by local governments (Hakim, 1987). Assessment taxes generated in the process become a major source of income for local governments. Therefore, tax becomes a large significant contributor to the source of income of a country. There are several assessment tax principles outlined, that is a rational tax system should be based on ability to pay the taxes, and capabilities of taxpayers should be evaluated in terms of its fairness, certainty of tax, not a burden and reasonableness (Md Zyadi, 1990).

The principle of justice is divided into two categories which are horizontal equity (horizontal fairness) and vertical equity (vertical fairness). Horizontal fairness means that the individual has an assessment tax liability to pay at the same flat rate with other individuals, while vertical fairness refers to a situation where different individuals with differing income levels are paying tax at differing amounts. The principle of tax certainty refers to the procedures and rules of taxation which should be clear and easily understood by the individuals subject to tax. A tax system (Kuppusamy, 2008) clearly need to have the four elements above that could ascertain the tax liabilities incurred, be able to ensure that those who pay taxes could do so and to estimate the revenue from tax collection to be realistic. A very important element in the principle of assessment tax is that it does not burden the taxpayers. This refers to the concept of public utilities where a portion of taxpayers' income is needed to pay taxes, as well as paying for some other expenses and in other words, taxpayers are able and capable to pay the tax. Reasonable refers to an "economic" situation, linked to the concepts discussed above where taxpayers are not burdened with high financial responsibility. It also affects the principle of "willingness to pay" which is subjective and depends on the level of influence received by individuals as paying tax (Gibson \& Virgina, 1998).

The assessment tax serves to divide income which involves the community. When the tax is levied, the taxpayer's income for distribution to others lessens. In the context of assessment tax, enforcement of the tax is intended as a tool to drive the development of an area administered by local governments. Assessment tax imposed on the taxpayer is given back by local governments in the form of services in their respective administrative areas (Ismail, 2008). The imposition of assessment tax is related to the role of local governments in developing the area and providing the necessary services and facilities. According to Section 127 of the Local Government Act 1976, local governments are empowered to impose assessment tax on property owners to carry out the functions and roles of local governments as an organisation which has autonomy over the local populace. In addition, the statements below show the purposes of the assessment tax:

(1) As a fund for the construction of development projects in their administrative areas;

(2) To provide basic facilities and good infrastructure such as provision of street lighting and signage;

(3) Maintenance and cleaning of roads, drains and drainage;

(4) To provide and maintain parks and public recreation areas;

(5) To provide and maintain a public cemetery;

(6) To provide and maintain public markets, bus stops, public halls, stadiums and so on;

(7) To develop and maintain the administrative landscape morphology;

(8) Maintain cleanliness and combating pollution of the river;

(9) Maintain public health.

Local governments have important responsibilities in carrying out their functions and roles, especially in assessment tax management to ensure the welfare and amenity of residents can be realised. If the local 
government is weak and incompetent in handling the management of the assessment tax it would certainly affect the results of tax collection which is to be used as financing development projects and services provided (Buang, 2000). In addition, the arrears in assessment taxes will increase due to poor management and will burden the local governments. This will have an impact on the quality of work and services performed.

Local governments are given the authority to mete out appropriate actions by several statutes to make sure its role as local governments is run in an orderly and effective manner. The statutes include the three major local governments acts, namely the Local Government Act 1976 (Act 171), the Town and Country Planning Act 1976 (Act 172) and the Street, Drainage and Building Act 1974 (Act 133). In addition, there are policies that serve as a government strategy to ensure the smooth running of local governments' management and provision of services.

The government has introduced various programs to improve the quality of public services. For the implementation of MS ISO 9000, there are programs which aim to improve quality which including Working Procedure Manual (SIM) and Table File (FM), Quality Counter Service, Quality Improvement Group (KMK), Micro Accounting Systems (SPM), Total Quality Management (TQM) and Clients Charter (Ahmad Atory, 1991).

MS ISO 9000 is a system that sets the standards and lists of elements that are needed in the quality system of an organisation to ensure that services provided meet customer requirements. MS ISO 9000 standards require organisations to identify their customers' needs, and planning and control processes that should be implemented to fulfil the requirements, providing appropriate and adequate training for personnel involved in quality systems and conducting audits to ensure the effectiveness of the processes in the system in achieving quality objectives.

Clients Charter (Piagam Pelanggan) has been introduced to further improve the ability of government agencies at either federal state or local government in providing quality services to their customers. The implementation of these programs also provides a basis for forming a system of quality management in the public service. In addition, a Star Rating System (SSR-PBT) has been introduced in local governments which were conceived by the former Prime Minister Tun Abdullah bin Ahmad Badawi. SSR-PBT is designed to enhance the delivery and improvement of government system providing services to citizens. The purpose of this system is to evaluate the performance of local government services, putting local governments at the appropriate position in the rankings so that local governments can improve their competitiveness, and to keep and maintain the level of efficiency and effectiveness of high performing local governments.

Assessment tax management is a process or activity conducted by local governments to impose a tax on holdings situated within their administrative areas. Local governments are given the power to impose rates on holdings by section 127, Local Government Act 1976 to carry out its role efficiently and effectively to manage the tax. However, what is more important is the availability of policies and laws as required, which should be strengthened so that they would be more capable of dealing with challenging issues that refer to general tax management (Ahmad \& Hasmah, 1997).

\section{Methodology}

The research methodology is to adopt a case study approach. There are many concepts and definitions of case studies used in research which differ and contradict with each other. A simple definition of a case study is that it provides descriptive accounts of one or more cases and goes on to say that the case study is the social 
equivalent of the spotlight or microscope (Yin, 2002). The other definition of case study is where it elaborates on the case study research as an empirical inquiry that investigates a contemporary phenomenon and context are not clearly evident.

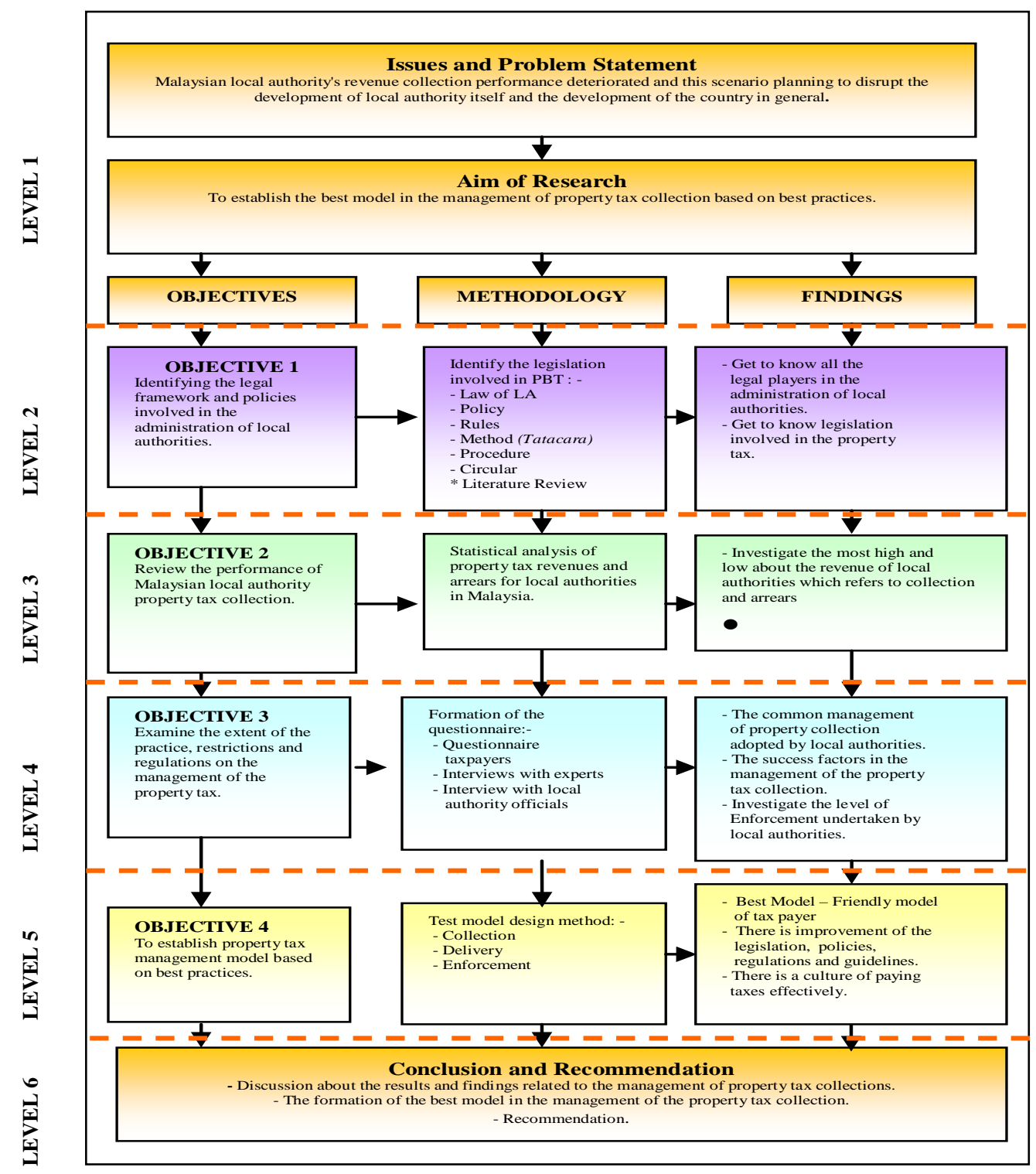

Figure 1. Flow chart of research framework.

Figure 1 shows the flow of the research. Firstly, the first 1evel discusses about the issues and states the problem statement touching on the deterioration of Malaysian local governments' revenue collection performance and how this scenario could lead to disruption of the local governments' development and the country in general. From the problem statement and issues arising, the aim of the research is set up.

This research starts by reviewing literature from journals, thesis, articles, books and web pages. Reviews of the literature are the studies carried out from the source to provide a clear comprehension of the subject matter during the early stages of the research. This preliminary study involves the retrieval of information on local government administration which includes background, definitions, objectives, authority and hierarchy, 
functions and roles of local governments from legal perspectives. Problems and obstacles that interfere with the smooth administration of local governments are also described as well as legal enforcement measures undertaken by local governments. This can be referred to in level 2, Figure 1 which would achieve the first objective of this research.

Having identified the problems, the objectives and scope are determined for this study. Data and information would be collected based on the requirement that the objectives can be achieved with precision. Collection of data and information are very important and it can consist of primary and secondary data. Primary data obtained directly from field works or case study data are extremely important in achieving the objectives that have been determined, so are the data obtained from secondary sources during the early stages. Data from secondary sources will assist the researcher in the development of survey questions through case studies for garnering primary data. Level 3, Figure 1 refers to the data of statistical analysis of assessment tax revenues and arrears of local governments in Malaysia needed to review the performance of Malaysian local governments' assessment tax collection.

In level 4, a questionnaire survey and interview are conducted focusing on the local governments' administration to examine the extent of the practice, restrictions and regulations with regard to the management of the assessment tax. While for level 5 , the test model design method focusing on collection, delivery and the enforcement of assessment tax in local governments in Malaysia will be conducted. Finally, at the end of this research the best model with a taxpayer-friendly concept will be established as a best practice model for local governments. Meanwhile, the most important thing is improvisation of legislations, policies, regulations and guidelines in the assessment tax management. Concurrently, a culture of paying taxes will be inculcated among the taxpayers as it becomes an obligation to them.

Once the data and information are available, data analysis will then be performed to achieve the objectives that have been determined. This stage is very important in determining the achievements of the objectives. Some of the objectives outlined will be reviewed and analyzed by using appropriate methods either qualitatively or quantitatively. In final stage, the conclusion and recommendations are made to the study. Description of the findings described above will be based on the analysis of the results obtained for the four objectives. Level 6 will discuss about the results and findings which are related to the management of assessment tax collections, the formulation of the best model in the management of the assessment tax collection and lastly but not least, the recommendations based upon the findings of the research.

\section{Findings}

\section{Assessment Tax Revenue Performance (2004-2008)}

Local assessment tax revenue performance overall between three levels can be described by Figure 2 as shown below. An analysis of assessment tax revenue for the past four consecutive years showed the Board/City Council listed the percentage of total proceeds from the highest level and the Regional Council. Results of analysis for the revenue of assessment tax are $86.48 \%$ with a performance status of the Board/City Council is very good. For the Regional Council recorded a total revenue of tax collection stood at $84.20 \%$ while the District Council, good be in a position moderate percent rate about $74.31 \%$.

Table 1 and Figure 3 show the performance of local government assessment tax revenue between the 
states for 2004 to 2008. Decision analysis found that the state had recorded the percentage of assessment tax collection is excellent Penang by $\mathbf{9 4 . 1 2 \%}$. This was followed by Perak, Negeri Sembilan, Selangor, Johor, Malacca, Pahang and Sarawak to the position where the performance is very good percent are between $80 \%$ to $87 \%$. Only the state is in the excellent recorded $75.71 \%$. For other states like Terengganu, Kelantan and Kedah were performed with the rate of assessment tax collection percentage of $60 \%-65 \%$ (satisfied) and the lowest performance state refers to Perlis by with the percentage of $54.76 \%$.

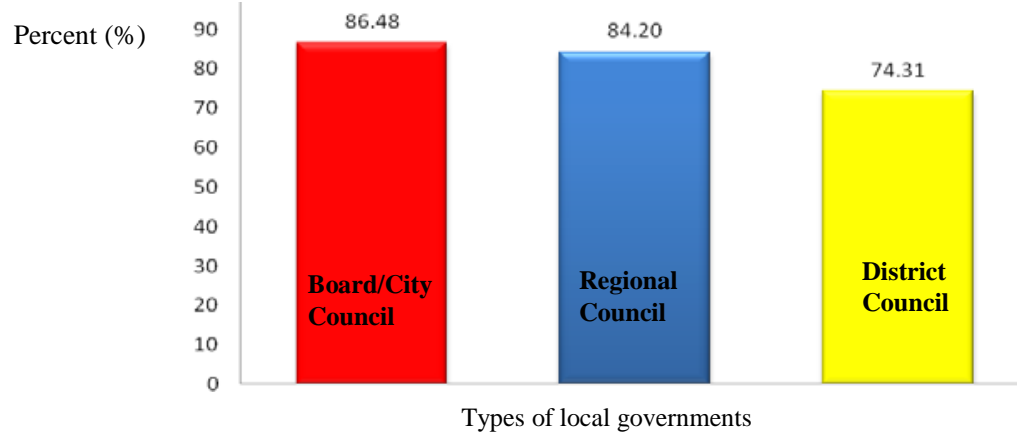

Figure 2. Assessment tax revenue performance between local governments within 2004-2008.

Table 1

Local Assessment Tax Revenue Performance of the State for the Year 2004-2008

\begin{tabular}{rlrl}
\hline No. & State & Total average $(\mathrm{RM})$ & Percent (\%) \\
\hline 1 & Pulau Pinang & $103,961,313.57$ & 94.12 \\
2 & Perak & $8,292,980.58$ & 87.43 \\
3 & Negeri Sembilan & $10,628,481.39$ & 86.78 \\
4 & Selangor & $59,612,590.77$ & 84.82 \\
5 & Johor & $17,098,607.68$ & 84.08 \\
6 & Melaka & $26,716,941.53$ & 82.64 \\
7 & Pahang & $6,291,534.75$ & 82.59 \\
8 & Sarawak & $5,603,696.41$ & 80.19 \\
9 & Sabah & $3,399,262.84$ & 75.71 \\
10 & Kedah & $5,433,322.61$ & 64.75 \\
11 & Kelantan & $1,629,437.60$ & 60.13 \\
12 & Terengganu & $7,093,312.88$ & 60.08 \\
13 & Perlis & $3,905,559.25$ & 54.76 \\
\hline
\end{tabular}

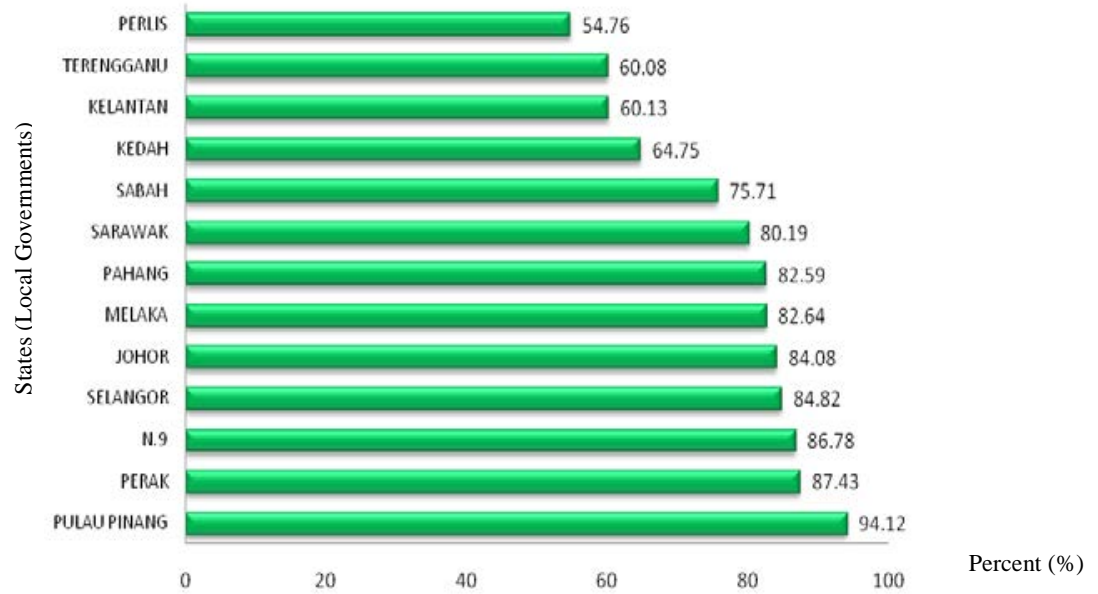

Figure 3. Local assessment tax revenue performance of the state for the year 2004-2008. 
Table 2

Statistic Performance of Assessment Tax Revenue in Local Governments (2004-2008)

\begin{tabular}{lllll}
\hline No. of LA & $\%$ & Gred & Performance $\%$ & Status \\
\hline 28 & 24 & A+ & $90-100$ & Excellent \\
32 & 27 & A & $80-89$ & Very good \\
17 & 14 & A- & $75-79$ & Good \\
14 & 12 & B $^{+}$ & $70-74$ & Moderate \\
3 & 3 & B & $65-69$ & Moderate \\
6 & 5 & B- & $60-64$ & Satisfied \\
5 & 4 & C+ & $55-59$ & Less satisfied \\
4 & 3 & C & $50-54$ & Less satisfied \\
3 & 3 & C- & $45-49$ & Less satisfied \\
2 & 2 & D+ & $40-44$ & Not satisfied \\
3 & 3 & D & $35-39$ & Not satisfied \\
0 & 0 & D- & $30-34$ & Not satisfied \\
2 & 2 & E & $0-29$ & Weak \\
\hline 119 & $100 \%$ & & & \\
\hline
\end{tabular}

\section{Assessment Tax Arrears Performance (2004-2008)}

Based on the Grading System, as a whole local governments in Malaysia there are only 28 of the local governments received a grade A+ (excellent), 32 grades A and $17 \mathrm{~A}$ - grades in their respective positions of good very and good. For grade $\mathrm{B}+$ and $\mathrm{B}$, there are $17 \mathrm{LA}$ in a position moderate. While six local governments in the grade of B- (satisfied). A total of 12 function representing $\mathrm{C}+, \mathrm{C}$ and $\mathrm{C}$, the status is less satisfied. Grade $\mathrm{D}+$ and $\mathrm{D}$, there are five local governments in the not satisfied levels. However, the majority of the local governments was ranked very good (grade A) in the performance of assessment tax revenue.

Table 3 and Figure 4 show the performance of local government assessment tax arrears of the state for the years 2004 to 2008. Decision analysis found that the state had recorded the percentage of assessment tax arrears is the highest state of Johor. Even so, the percentage recorded performance is still low at $47.13 \%$ (grade C-).

Table 3

Local Assessment Tax Arrears Performance of the State for the Year 2004-2008

\begin{tabular}{llrl}
\hline No. & State & Total average & Percent (\%) \\
\hline 1 & Johor & $2,664,357.42$ & 47.13 \\
2 & Selangor & $10,327,638.01$ & 43.33 \\
3 & Melaka & $4,182,028.36$ & 37.16 \\
4 & Pahang & $803,961.32$ & 31.40 \\
5 & Kedah & $1,621,578.00$ & 30.40 \\
6 & Sabah & $1,008,345.60$ & 28.59 \\
7 & Perak & $1,082,113.51$ & 27.64 \\
8 & Negeri Sembilan & $1,309,444.01$ & 26.35 \\
9 & Pulau Pinang & $11,624,867.14$ & 23.77 \\
10 & Sarawak & $675,447.51$ & 19.87 \\
11 & Kelantan & $637,359.02$ & 15.36 \\
12 & Perlis & $922,718.25$ & 10.88 \\
13 & Terengganu & $668,047.81$ & 8.95 \\
\hline
\end{tabular}




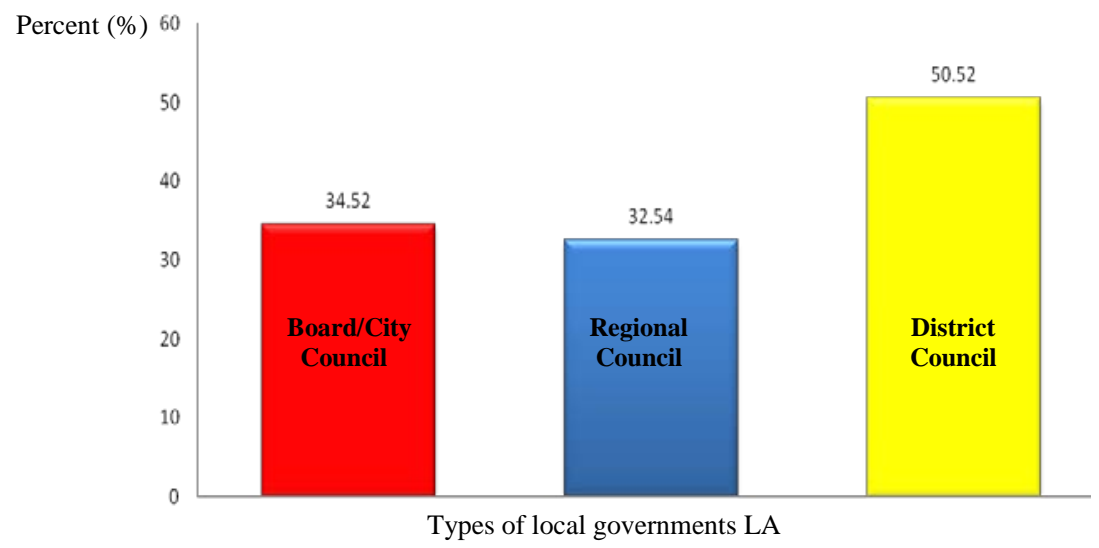

Figure 4. Local assessment tax arrears performance of the state for the year 2004-2007.

State local governments in the performance of overall local governments, which had the lowest percentage rate of only $8.95 \%$ of the weak position with a grade E. Ranking second is Johor, Selangor rate, is $43.33 \%$ percent. For the next are Malacca, Pahang and Kedah in the not satisfied level between $30 \%-37 \%$. This is followed by Sabah, Perak, Negeri Sembilan, Penang, Sarawak, Kelantan and Perlis. To all of the state to perform weak in assessment tax collections over the past four consecutive years, the percentage of $10 \%$ to $28 \%$ only (see Figure 5).

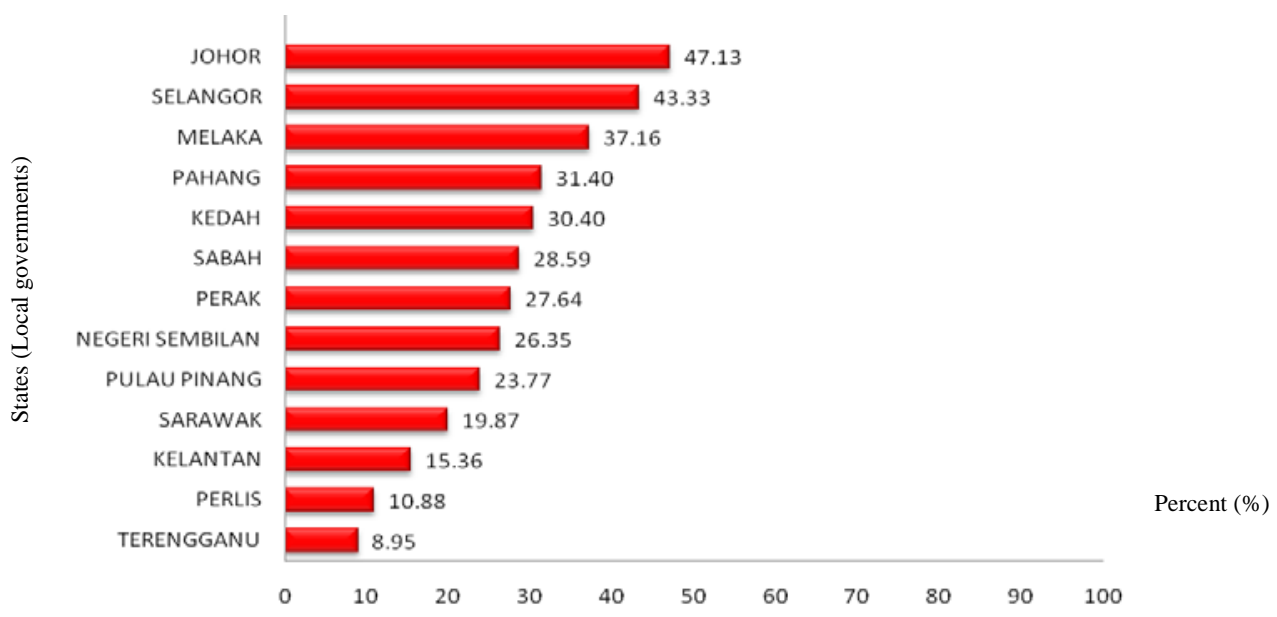

Figure 5. Local assessment tax arrears performance of the state for the year 2004-2008.

Based on the Grading System, as a whole of local governments in Malaysia there are only four of the local governments received a grade A+ (excellent), 10 local governments with the grade $\mathrm{A}$ and eight of local governments with the $\mathrm{A}$ - grades in their respective positions good and very good. For grade $\mathrm{B}+$ and $\mathrm{B}$, there are 10 units of the District Council in a position moderate. While a District Council is at the grade of B-satisfied. A total of six function representing $\mathrm{C}+, \mathrm{C}$ and $\mathrm{C}$, the status is not satisfied. For grade $\mathrm{D}+$ and $\mathrm{D}$, there are 10 local governments in the not satisfied level.

However, the majority of the local governments with the number of 49 were ranked low (grade E) in the performance of assessment tax arrears. Overall, the average performance of the assessment tax proceeds to local governments is about $41 \%$. This shows that the performance of the assessment tax proceeds of the Local 
District Council for four consecutive years (2004-2008) is located at the moderate level (see Table 4).

Table 4

Statistic Performance of Assessment Tax Arrears in Local Governments (2004-2008)

\begin{tabular}{rrlll}
\hline No. of local governments & $\%$ & Grade & Performance (\%) & Status \\
\hline 4 & 3 & A & $90-100$ & Excellent \\
10 & 8 & A & $80-89$ & Very good \\
8 & 7 & A- & $75-79$ & Good \\
8 & 7 & B + & $70-74$ & Moderate \\
2 & 2 & B & $65-69$ & Moderate \\
1 & 1 & B- & $60-64$ & Satisfied \\
3 & 3 & C+ & $55-59$ & Less satisfied \\
5 & 4 & C & $50-54$ & Less satisfied \\
5 & 4 & C- & $45-49$ & Less satisfied \\
3 & 3 & D+ & $40-44$ & Not satisfied \\
11 & 9 & D & $35-39$ & Not satisfied \\
10 & 8 & D- & $30-34$ & Not satisfied \\
49 & 41 & E & $0-29$ & Weak \\
\hline 119 & $100 \%$ & & & \\
\hline
\end{tabular}

\section{Expected Result}

The end result of this study is to establish a model of assessment tax management in Malaysia. This model will be in the form of a taxpayer-friendly concept or model that will change the current collection performance and arrears of assessment taxes in local governments, thus ensuring the effective tax revenue collection by local governments in Malaysia. The outcome of this research is expected to be a workable model that is able to overcome the deficiencies of the existing model as well as having the ability to measure current and future needs accurately. At the same time, it is envisaged that the tax payer would be satisfied with the new system.

\section{Conclusion}

With a working model for the efficient management of assessment tax, revenues will be maximized through the outstanding performance of local governments and arrears will also decrease. Thus, with high yields local governments will be able to implement and fulfill the desires of taxpayers for the provisioning of appropriate services. If there are poorly executed, tax equity will suffer, revenue generation may also suffer and public acceptance will erode.

\section{References}

Ahmad Atory, H. (1991). Kerajaan Tempatan di Malaysia. Dewan Bahasa \& Pustaka.

Ahmad, A., \& Hasmah, A. Z. (1997). Pengenalan kepada Undang-Undang Kadaran di Malaysia. Universiti Teknologi Malaysia, UTM.

Bardai, B. (1987). Percukaian: Prinsip dan Amalan di Malaysia (M. Mngt. thesis, DBP Kuala Lumpur).

Buang, A. (2000). Analysis of factor that contributes to the accumulation of uncollected rates in local governments in Malaysia. Universiti Teknologi Malaysia, UTM.

Gibson \& Virginia. (1988). Scope in portfolio management. Seminar Pengurusan Harta Tanah Kuala Lumpur. 
Hakim, C. (1987). Research design: Strategic and choices in the design of social rresearch. London: Allen \& Unwin. Ismail, A. (2008). Pematuhan Pembayaran Cukai Pintu di Majlis Perbandaran Sibu (UTM, thesis, Universiti Teknologi Malaysia). Kuppusamy, S. (2008). Local Government in Malaysia: Back to Basics and the Current Scene. Journal of Malaysian Chinese Studies, 11, 77-96.

Md Zyadi, Md. T., \& Ragayah, M. Z. (1990). Ekonomi Percukaian (M. Mngt. thesis, DBP Kuala Lumpur). Johor State Government. (2009). Report of Johor State Assembly Meeting.

Sidek Hassan, D. (2008). Ketua Setiausaha Negara, Utusan Malaysia Newspaper.

Sri Hana Dranita, J. (2006). Prestasi Kadaran: Kajian Terhadap Masaalah dalam Pengutipan Cukai Harta, Majlis Perbandaran Kulai (D. Mang. thesis).

Yin, R. K. (2002). Case study research: Design and methods. London: Sage. 